\title{
KÖNYVJELZÖ
}

\section{HUBAI JÓZSEF: AZ UNIÓS CSATLAKOZÁS HATÁSA MAGYARORSZÁG TERMÉSZETI ERŐFORRÁS-GAZDÁLKODÁSÁRA}

\author{
(Nemzeti Tankönyvkiadó, Budapest, 2006, 174 o.)
}

\section{KRISZTIÁN BÉLA}

Az ország kritikus energiafüggỏsége régtől ismert tény. Az újabb események fényében azonban ismételt áttekintése és az európai kapcsolatrendszerben történő értelmezése fontos eleme mindennapjainknak. Az uniós csatlakozás elött a hazai energiaszektorra ajánlott átszervezések, a gazdasági értékelések következtében a privatizációs előnyök hangsúlyozása mellett kissé elfedett volt a hazai természeti erőforrások értéke, hasznosításának lehetősége. A rendszerelvü komplex megközelités jegyében vehetjük kézbe Hubai József: Az uniós csatlakozás hatása Magyarország természeti erooforrás-gazdálkodására címü munkáját. A nyolc föfejezetbe rendezett szakmai anyag geográfiai kiindulópontból közelíti a sokrétü témát. Ez egyben jelzi a földrajzi szemlélet kitüntetett voltát, a szakföldrajzok szerepét, amit szerzőnk a „külgazdasági földrajz” leírásával mutat be. Az egyes fejezetek (I. A természeti erőforrások kutatásának geográfiai irányzatai; II. A természeti erőforrások gazdasági szerepe, értékelésük szempontjai; III. Természeti erőforrásaink általános bemutatása; IV. Természeti erőforrásaink részesedése, súlya nemzeti vagyonunkban; V. Természeti erőforrásaink megoszlása és térbeli szóródása; VI. Hazánk külkereskedelmének rövid bemutatása; VII. Természeti erőforrásainkkal összefũggő ügyletek; VIII. Uniós csatlakozásunk kérdőjelei; majd a IX. Befejezés) a leíró és értékelö, kritikai részek változatosságával tárják fel a hazánk területi értékéböl eredő kihasználható lehetőségeket és megtörtént eseményeket. Szerzőnk szerint is a kedvező földrajzi helyzet kiaknázása azonban nem tapasztalható. Megjegyezzük, hogy szerzőnk példái jók, de hozzátehette volna: a Duna hajózhatósága a hiányzó nagymarosi létesítmény miatt korlátozott, az országot kelet-nyugati irányban átszeló autópályák az országon való áthaladás gyorsaságát növelik a vonzóbb befektetési és üdülöterületek irányába. Figyelemreméltó a természeti eröforrások értékelésének árnyalt bemutatása, amelyben mára új szempontok is érvényesülnek. A globális összefüggésekre kitekintéseket nyújtó és a külkereskedelmi ügyleteket bemutató fejezetrészek azt a sokrétü kapcsolatrendszert tárják fel, melyet egy külpiacra orientált gazdaság energiaszükségletei érdekében szükségszerüen megoldani kényszerül. $\mathrm{Az}$ energia-kapcsolatrendszer termelés- és általános, társadalompolitikai kérdés 
volt, és az is marad. Az energia korszakonként változó súllyal kezelt volta ellenére Hubai József kötete az aktuális és megoldandó kérdésekre is összpontosít: az uniós csatlakozással felmerülő kérdések célorientált felsorolása és a lehetséges megoldások feltételei továbbgondolkodásra késztetnek. A könyv alkalmas arra, hogy az olvasó komplex formában szembesüljön a csatlakozással más viszonylatba került versenyképesség-vesztéssel, az energia értéken történő kezelésével. Ez különösen a külkereskedelmi relációkat érintő részekben, majd a Befejezésben válik konkréttá. A mủ a kérdések csomóponti megközelítéseivel igyekszik azt az ellentmondást feloldani, hogy a tárgy tekintetében meghatározó hosszú folyamatokkal vagy a részletekkel foglalkozzon. Szerzőnk a szakértő lektorral, dr. Süli-Zakar István professzorral együtt jól oldja meg a feladatot: az arányos szerkesztés és súlyozott tartalom jól tükrözi a 21. századba lépett ország természeti erőforrás-gazdálkodásának nemzetbiztonságilag, stratégiailag is fontos tevékenységét. A szerzỏ számos térképpel, ábrával szemlélteti a gazdag anyagot, segítve a sokrétú ismeretanyag megértését. 


\title{
PAP NORBERT: KISTÉRSÉGFEJLESZTÉS
}

\section{A KISTÉRSÉGFEJLESZTÉS ELMÉLETE ÉS GYAKORLATA MAGYARORSZÁGON A RENDSZERVÁLTÁS UTÁN}

\author{
(Alexandra Kiadó, Pécs, 2007, 200 o.)
}

\section{LUDESCHER GABRIELLA}

A „Kistérségfejlesztés” című könyv elérte előszóban megfogalmazott célját, olyan tankönyv, szakkönyv lett, amely segít a kistérségfejlesztéssel kapcsolatos kérdések megválaszolásában. A kötet elsősorban segítséget nyújt abban, hogy részletesen megismerjük a kistérségek kialakulását, típusait, cél- és eszközrendszerét, partneri környezetét, a területfejlesztési koncepciókat és programokat, valamint tematikus utakat és innovációs eszközöket. Másodsorban az „Egy rurális mintatérség: kistérségi szerveződések Tolna megyében" címü fejezetében betekintést enged egy megye valódi kistérségi szerveződéseibe, és tárgyalja a kistérségek jövőjét is. A szerző a három részre tagolható alkotásának végén, az első függelékben a pályázatírási technikát vázolja fel, a második függelékben pedig módszertani segítséget kíván nyújtani a jellemzően rurális kistérségi területek fejlesztési terveinek elkészítéséhez.

A szakkönyv jobb megismertetése céljából szükségesnek látjuk sorba venni a könyv tíz fejezetét, valamint két függelékét is.

Az első fejezet - A kistérségek földrajzi kérdései - bemutatja, hogy mit nevezünk kistérségnek, milyen nagy földrajzi gondolatrendszerek, térfelfogások alakultak ki. Továbbá összefoglalóan ismerteti a napjainkban Magyarországon élő térkategóriarendszereket, melyeket közismert kutatók dolgoztak ki (Krajkó Gyula, Nemes Nagy József, Süli-Zakar István és Tóth József). A szerző által szerkesztett táblázatok segítik az Olvasót a térszerkezet, térrendszerek megismerésében.

A könyv második fejezetében - A kistérségek kialakulása, típusai Magyarországon - a szerző röviden ábrázolja a magyar kistérségtörténetet, a társulások kialakulásának, müködésének jogi hátterét, a kistérségek tipológiáit, valamint a kistérségek együttmüködésének hatékonyságát és gátját. A kitünő stílusban megírt és kellőképpen részletes fejezet megfelelő információt nyújt mindazok számára, akik többet akarnak megtudni a kistérségek kialakulásáról és típusairól.

A harmadik fejezet - A kistérségfejlesztés cél- és eszközrendszere - bemutatja azokat a célokat, amelyek mentén a tevékenységek szerveződnek, valamint a kistérség eszközrendszerét, a regionális politika eszközeit. Ezen túl rámutat az eszköz- 
rendszer egyéb elemeinek felhasználására (vállalkozói övezetek, ipari parkok, központi nagyberuházások, kistérségmarketing, oktatás, képzés stb.).

A negyedik fejezetben - A kistérségek a magyar területfejlesztés intézményrendszerében, és partneri környezetük - a hazai területfejlesztés intézményrendszerét mutatja be a szerző, valamint a területfejlesztési partnercsoportok: kormányzat, önkormányzatok, magánszféra, vállalkozások, önkéntes és közösségi szféra, EU-s szervezetek, nemzetközi partnerségi szervezetek motivációiról olvashatunk.

$\mathrm{Az}$ ötödik fejezet - Területfejlesztési koncepciók és programok a kistérségek számára - a területi tervezés módszertanát írja le, mely segítséget nyújt a területtervezőknek a koncepciók és a programok elkészitésében. E módszertani leírásra nagy szükség mutatkozik a szakma mủvelői részéröl, hiszen az eddig (2004-2006; 2007-2013 közötti időszakra) elkészült koncepciók, programok színvonala nem mindig felel meg a követelményeknek.

A hatodik fejezet - A tematikus utak jelentősége - feltárja a hálózatos együttmüködést és ennek formáját, a tematikus utat, valamint ezek típusait, fóbb feladatait és sajátosságait. E fejezet a többihez hasonlóan gyakorlati tapasztalatot is bemutat, a tematikus út ismertetése kapcsán (Villány-siklósi borút), valamint néhány projektötletet is felvázol.

A könyv hetedik fejezetében - Innovációs eszközök - az innovációs intézmények hasznáról van szó. A szerző meglátása szerint ma a kistérségek számára az ipari parkok, inkubátorházak, teleházak, az úgynevezett innovációs központok jelenítik meg az innovációs intézményeket. A szerző részletekbe menően írja le a vállalkozásoknak nyújtandó szolgáltatások lehetséges körét.

A nyolcadik fejezetben - Az információs társadalom kihívásai - kerül sor az infokommunikációs eszközrendszer bemutatására. Továbbá a szerzö feltárja az Olvasó számára az információs forradalom kistérségek számára kínálkozó lehetőségeit is.

A kilencedik fejezet - Egy rurális mintatérség: kistérségi szerveződések Tolna megyében - betekintést enged egy, a szerzö által 2003-2004-ben vezetett, Tolna megyei vizsgálatba. E konkrét kutatáson keresztül megismerhetjük egy megye kistérségeinek adottságait, mind földrajzi, mind területfejlesztési aspektusait.

Az utolsó fejezet - A kistérségek jövője? - a legrövidebb fejezet, de egyben az egyik legérdekesebb része a könyvnek. A szerző téziseket fogalmaz meg a kistérség elkövetkezö tíz évével kapcsolatosan. Ezek a feltevések nagyon elgondolkodtatóak, ezért célszerü lenne, ha azon személyek is foglalkoznának a kistérségek jövőjével, akik döntéshozó pozícióban vannak.

A könyvben szereplö két függelék - A pályázatírásról; A rurális térségi komplex fejlesztési program készítésének módszertana -, ahogy a szerző az előszóban is írja, lazábban kapcsolódnak a könyv fentiekben bemutatott fejezeteihez. A recenzens véleménye szerint a pályázatírási technika bemutatása nem biztos, hogy teret kellene kapjon egy ilyen magas színvonalú, igényes könyvben. Bár nagy részletességgel íródott meg, ennek ellenére sem tud megfelelö eligazitást adni egy kezdỏ pályázatirónak. Álláspontunk szerint a könyv témáját és tartalmát figyelembe véve nem is 
tủzheti ki reális célként azt, hogy a pályázatírási technika módszerét a gyakorlat számára is alkalmazhatóan bemutassa.

A függelék másik írása módszertani segítséget kíván nyủjtani a jellemzően rurális kistérségi területek fejlesztési terveinek elkészítésére. Az Ormánság példáján keresztül megismerhetjük, hogy a fejlesztési terv elkészitése során milyen vizsgálati és bemutatási kritériumoknak kell eleget tenni.

A könyv erősségének tekinthetö, hogy gyakorlat-orientált, amivel kielégíti az Olvasó könyvvel szemben támasztott igényeit. A szerző didaktikus stílusa, könnyen értelmezhetó írásmódja, valamint a jól megszerkesztett és kellőképpen strukturált táblázatai könnyen olvashatóvá és magyarázóvá teszik a mondanivalót. A szerző írásában visszatükröződik az elméleti, szakmai látásmód és a gyakorlati tapasztalat is.

A könyv pozitívuma az is, hogy a szerzö nemcsak, hogy felismeri, hanem be is mutatja azon véleményét, miszerint az alapvetô kistérségfejlesztés titka nem csupán az anyagi forrásokon múlik, hanem a humán erőforrásokon is. A valódi fejlesztésekhez e két forrást kellene párhuzamosan és hatékonyan kihasználni.

A könyv eróssége mellett a recenzió írója hiányolja a még több és markánsabb fejlesztési ötletek bővebb ismertetését. Mint minden aktuális szakirodalomnál, itt is problémaként merül fel, hogy a könyv első változata 2005-ben készült (ezt a könyv 2005-ben írt előszavából tudhatjuk meg), és azóta a kistérségekben is több változás történt (pl. gyakorlatilag a legtöbb Többcélú Kistérségi Társulás rendelkezik web felülettel). A szerzö a könyv megjelenésekor szerencsére friss információkkal is ellátta írását, így valóban aktuális szakirodalmat tarthat kezében az Olvasó. Bekerültek a könyvbe a Nemzeti Fejlesztési Terv II. (Új Magyarország Fejlesztési Terv) Operatív Programjai is, de mindennek ellenére néhány résznél (pl. Az információs társadalom kihívásai) érzékelhetö, hogy korábban írta a szerző. A recenzens nem tarja szerencsésnek az ajánló bibliográfia helyét a 144-151. oldalon, kedvezöbb lett volna a szokásos módon a könyv végére elhelyezni. A színvonalas könyvben az egyes részek, fejezetek eltérỏ részletezettsége (pl. hetedik, nyolcadik fejezet), valamint a tartalomjegyzékből az alfejezetek címeinek és az ajánló bibliográfia megjelölésének elmaradása nehezíti a könyv használatát, bár összességében egy jól szerkesztett, az oktatás szempontjából didaktikus müról van szó.

Zárszóként elmondhatjuk, hogy a szerzö e könyve szakmai és oktatási szempontból értékes, legnagyobb erénye a tudományos jellege, valamint a könnyen értelmezhetősége és gyakorlatorientáltsága. Hozzájárul a szakemberek szakmai fejlődéséhez, és olyan összefoglalást nyújt a kistérséggel foglalkozók számára, amely nélkülözhetetlenné válhat a munkájuk során. 